\title{
Segmentasi Citra Pembuluh Darah Retina Menggunakan Operasi Morfologi Iteratif
}

\author{
Vita Nurdinawati ${ }^{1 *}$, Atika Hendryani ${ }^{1}$, dan Thareq Barasabha ${ }^{2}$ \\ ${ }^{1}$ Jurusan Teknik Elektromedik Poltekkes Kemenkes Jakarta II \\ Jl. Hang Jebat III/F3 Kebayoran Baru, Jakarta, Indonesia 12120 \\ ${ }^{2}$ Fakultas Kedokteran Universitas Brawijaya \\ $\mathrm{Jl}$. Veteran, Malang, Indonesia 65145 \\ "Corresponding author.Email: vita.nurdinawati.83@gmail.com
}

\begin{abstract}
Retinal vessel segmentation is part of the morphological extraction of retinal blood vessels that plays an essential role in medical image processing. Manual segmentation is possible to do, but it is timeconsuming and requires special operators. Moreover, the possibility of variability between operators is vast. This study aims to answer the shortcomings of the manual segmentation process by automatically segmenting retinal blood vessels. The main contribution of this study is the use of a simple method to iteratively segment retinal blood vessels. All processes in the segmentation are simulated using Matlab. The algorithm was evaluated by comparing the results of the automatic segmentation with 20 manually segmented images from the STARE dataset. The result show specificity $98.13 \%$, accuracy $93.60 \%$, sensitivity $56.42 \%$, precision $80.48 \%$, and the dice coefficient $64.06 \%$. In conclusion, the automatic retinal blood vessel image segmentation process worked well.
\end{abstract}

Keywords—retinal segmentation, medical image processing, iteration process

\begin{abstract}
Abstrak-Segmentasi citra pembuluh darah retina merupakan bagian dari ekstraksi morfologi pembuluh darah retina yang berperan penting dalam bidang pemrosesan citra medis. Segmentasi manual dimungkinkan untuk dilakukan, tetapi memakan waktu dan memerlukan operator khusus. Selain itu, kemungkinan terjadinya variabilitas antar operator sangat besar. Penelitian ini bertujuan untuk menjawab kekurangan proses segmentasi manual dengan melakukan segmentasi citra pembuluh darah retina secara otomatis. Kontribusi utama dari penelitian ini adalah penggunaan metode sederhana untuk melakukan segmentasi citra pembuluh darah retina secara iteratif. Semua proses dalam segmentasi tersebut disimulasikan dengan menggunakan Matlab. Algoritma dievaluasi dengan membandingkan hasil segmentasi otomatis dengan 20 citra yang disegmentasi secara manual dari dataset STARE. Hasil pengujian menunjukkan bahwa spesifisitas yang diperoleh sebesar $98,13 \%$, akurasi $93,60 \%$, sensitivitas $56,42 \%$, presisi $80,48 \%$, dan dice coefficient sebesar $64,06 \%$. Kesimpulannya, proses segmentasi citra pembuluh darah retina otomatis berjalan dengan baik.
\end{abstract}

Kata kunci- segmentasi retina, pemrosesan citra medis, proses iterasi

\section{PENDAhUluan}

Segmentasi citra pembuluh darah retina berperan penting dalam bidang pemrosesan citra medis khususnya dalam ekstraksi morfologi pembuluh darah untuk menghasilkan informasi yang berguna dalam diagnosis dan pemantauan penyakit mata seperti retinopati diabetik, glaukoma, hipertensi, arteriosklerosis, dan neovaskularisasi koroid [1] - [4]. Segmentasi diperlukan dalam proses ekstraksi ciri untuk mendapatkan berbagai fitur dan atribut perubahan morfologi [5]. Perubahan morfologi yang terjadi di antaranya adalah diameter, lekukan (tortuosity), serta pola percabangan pembuluh darah retina.

Segmentasi secara manual dimungkinkan, tetapi prosedur ini memakan waktu dan memerlukan operator khusus, selain itu, kemungkinan terjadinya variabilitas antar operator sangat besar [3]. Penelitian ini bertujuan untuk menjawab kekurangan proses segmentasi manual dengan melakukan segmentasi citra retina secara otomatis menggunakan proses iterasi.
Beberapa tahun terakhir telah banyak dilakukan penelitian untuk mengembangkan metode segmentasi citra retina secara otomatis [6] - [8]. Masalah yang masih dihadapi pada proses otomatis tersebut adalah perlunya penerapan teknik segmentasi citra yang tepat agar dapat mendeteksi struktur pembuluh darah secara akurat karena citra retina umumnya mempunyai kontras yang rendah antara pembuluh darah dengan background citra [6]. Masalah lain yang mungkin ditemui yaitu terdapatnya noise pada citra. Selain itu, kondisi patologis pada mata juga dapat menjadi hambatan tersendiri [7].

Beberapa penelitian telah mengembangkan berbagai metode segmentasi untuk memperoleh hasil ekstraksi yang optimal. Penelitian sebelumnya tentang segmentasi citra retina diusulkan pada [7]. Penelitian tersebut membagi proses segmentasi menjadi beberapa tahap, antara lain preprocessing, ekstraksi ciri, clustering, dan postprocessing. Hasil evaluasi pada penelitian tersebut menunjukkan bahwa nilai spesifisitas tertinggi pada dataset Structured Analysis of the Retina (STARE) diperoleh dengan menggunakan kombinasi filter Frangi dan fuzzy C-means sebesar 98,79\% dan akurasi tertinggi

Received 7 April 2021, Accepted 4 June 2021, Published 20 June 2021.

DOI: https://doi.org/10.15294/jte.v13i1.29747 
diperoleh dengan menggunakan kombinasi filter Gabor dan Kmeans sebesar 95,94\%. Penelitian [9] dan [10] menggunakan teknik Contrast Limited Adaptive Histogram Equalization (CLAHE) untuk memperbaiki kontras citra. Penelitian [9] melakukan segmentasi pembuluh darah dengan menggunakan beberapa teknik antara lain: Adaptive thresholding, Otsu thresholding, Fuzzy C-means, ISODATA, dan Bradley threshold. Pada penelitian tersebut didapatkan hasil bahwa teknik fuzzy $C$-means memiliki nilai akurasi tertinggi sebesar 93,66\% pada dataset STARE dan teknik Otsu thresholding memiliki nilai akurasi tertinggi yaitu $95,96 \%$ pada dataset DRIVE. Penelitian [5] mengusulkan coarse to fine algorithm untuk segmentasi pembuluh retina secara otomatis. Dari hasil evaluasi dengan menggunakan database STARE, diketahui bahwa spesifisitas metode tersebut sebesar 94,43\%. Penelitian [11] menggunakan metode sederhana untuk melakukan segmentasi meliputi ekstraksi kanal hijau, filter Gaussian dan filter Wiener, Otsu thresholding, operasi morfologi opening untuk menghilangkan noise serta transformasi Hough untuk menghilangkan batas lingkaran daerah retina. Penelitian [12] menggunakan teknik supervised di mana operasi machine learning digunakan untuk mempelajari dan membuat keputusan berdasarkan data yang diperoleh dari proses training. Segmentasi dalam penelitian [12] terdiri dari fase training, fase testing, dan postprocessing. Proses training terdiri dari beberapa tahap antara lain preprocessing, enhancement, dan augmentasi data. Operasi machine learning yang digunakan dalam penelitian [12] adalah jaringan konvolusi penuh yang akan mengklasifikasikan piksel pembuluh darah dan piksel selain pembuluh darah dari citra retina.

Penelitian ini bertujuan untuk membuat sistem segmentasi citra pembuluh darah retina secara otomatis menggunakan operasi morfologi iteratif. Metode ini cukup sederhana, mempunyai kompleksitas rendah dan mudah diimplementasikan.

\section{METODE}

Segmentasi citra pembuluh darah retina secara otomatis dalam penelitian ini dilakukan dengan beberapa tahap operasi yang secara keseluruhan ditunjukkan pada Gambar 1. Citra kanal hijau diperoleh dari citra warna retina dan dilakukan perbaikan kontras. Operasi morfologi yang dipilih dalam penelitian ini yaitu transformasi Tophat untuk merekonstruksi pembuluh dengan memilih struktur elemen S1 yang diikuti dengan filter Wiener. Langkah selanjutnya adalah binerisasi dengan metode Otsu. Citra biner dalam Region of Interest (ROI) diperoleh dengan operasi logika AND antara citra hasil metode Otsu dengan masking citra retina dan dilanjutkan dengan pembuangan noise pada objek yang lebih kecil dari S3. Proses segmentasi ini dilakukan kembali secara iterasi menurun dengan struktur elemen dari S1-1 sampai S2. Semua tahap segmentasi citra pembuluh darah retina diimplementasikan dengan menggunakan perangkat lunak MATLAB.

\section{A. Dataset Citra Retina}

Penelitian ini menggunakan dataset STARE sebagai data citra dan juga sebagai ground truth. STARE merupakan dataset yang tersedia secara publik dan umum digunakan sebagai bahan pembanding dalam mengevaluasi metode segmentasi otomatis pembuluh darah citra retina. Citra dan data klinis dalam STARE diperoleh dari Shiley Eye Center di Universitas California, San Diego, dan oleh Veterans Administration Medical Center di San Diego. Dataset STARE terdiri dari 20 citra fundus retina dalam format RGB yang diambil dengan menggunakan kamera fundus TopCon TRV-50 dengan field of view $35^{\circ}$ dan kemudian didigitalisasi ke dalam $700 \times 605$ citra digital [13]. Sebanyak sepuluh citra berasal dari subjek normal dan sepuluh citra yang lain memiliki kondisi yang patologis. Sebanyak 20 citra warna retina tersebut masing-masing telah disegmentasi secara manual oleh dua pengamat berbeda dan disimpan di dalam dataset STARE sebagai ground thruth. Segmentasi manual dilakukan menggunakan alat bantu seperti dijelaskan dalam penelitian [14] dengan menandai atau memberi label untuk setiap piksel pada citra sebagai piksel pembuluh darah atau piksel selain pembuluh darah. Proses pelabelan citra ini membutuhkan waktu beberapa jam atau bahkan lebih lama, tergantung operator dan citra retina yang disegmentasi secara manual [14]. Walaupun terdapat citra warna retina dan citra hasil segmentasi, tetapi dalam dataset tersebut tidak terdapat citra masking sebagai ROI. Seluruh citra retina dalam dataset STARE disimpan dalam format PPM.

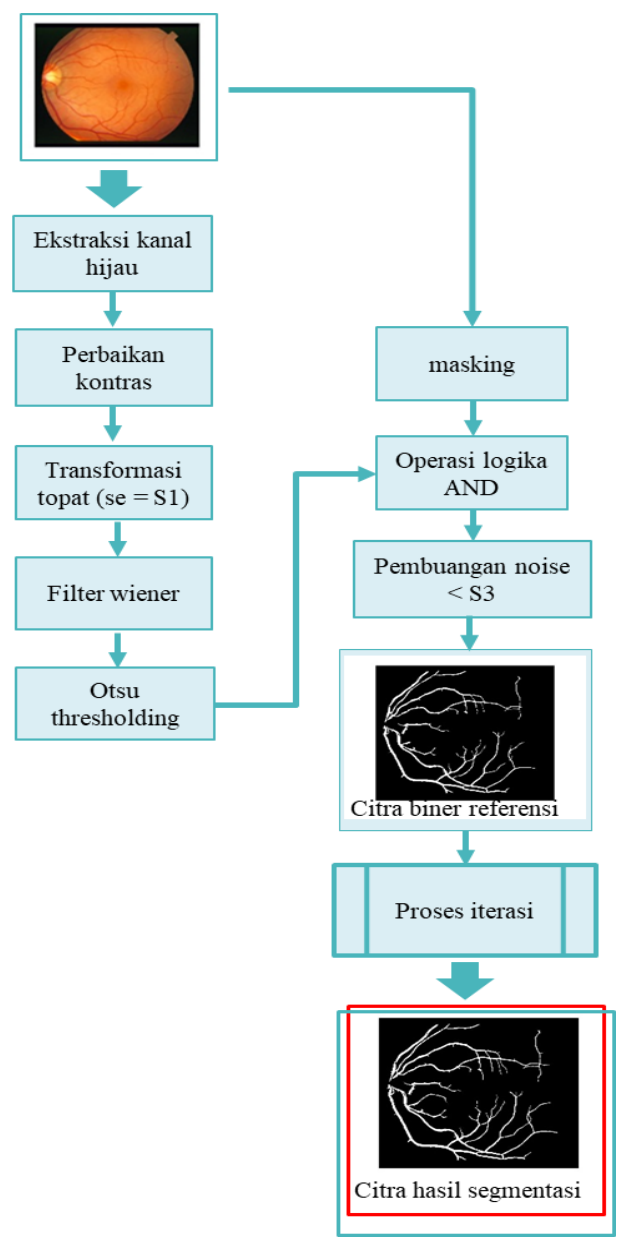

Gambar 1. Blok diagram proses segmentasi pembuluh darah citra retina

\section{B. Preprocessing}

Tahap ini bertujuan untuk memperbaiki kualitas citra, menyamakan background, serta meningkatkan kontras beberapa bagian citra yang penting sehingga lebih mudah diproses pada tahap selanjutnya. Tahap preprocessing ini meliputi ekstraksi kanal hijau dan perbaikan kontras.

\section{1) Ekstraksi Kanal Hijau}

Ekstraksi kanal dilakukan untuk memilih kanal mana dari citra tersebut yang mengandung paling banyak informasi. Seperti ditunjukkan pada Gambar 2, kanal hijau mempunyai kontras antara pembuluh darah dengan background citra yang lebih baik. Hal ini disebabkan karena cahaya hijau paling besar 
diserap oleh hemoglobin yang teroksigenasi (oxyhemoglobin) dan hemoglobin yang tidak teroksigenasi (deoxyhemoglobin), sehingga mempunyai lebih banyak informasi dibandingkan dengan kanal merah atau kanal biru [15], [16].

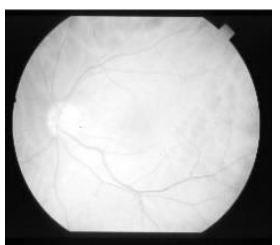

(a)

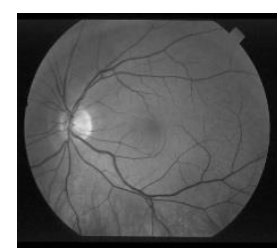

(b)

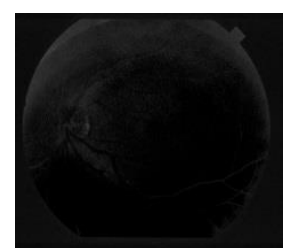

(c)
Gambar 2. Ekstraksi kanal dari citra retina RGB (a) kanal merah, (b) kanal hijau, dan (c) kanal biru

\section{2) Perbaikan Kontras}

Perbaikan kontras ini dilakukan untuk meningkatkan kontras dari citra level keabuan. Pada tahap ini, citra kanal hijau dalam bentuk citra keabuan yang sebelumnya telah dikomplemen, ditingkatkan intensitasnya dengan fungsi imadjust untuk memetakan nilai intensitas pada citra awal menjadi nilai intensitas baru. Citra retina hasil pengaturan intensitas ditunjukkan pada Gambar 3.

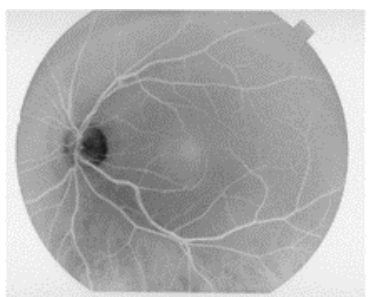

(a)

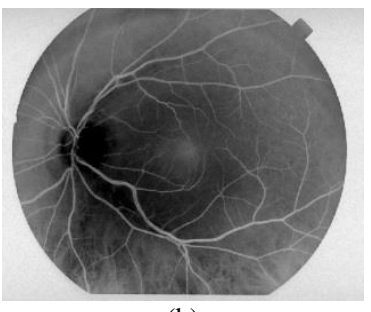

(b)
Gambar 3. Citra retina keabuan (a) sebelum perbaikan kontras dan (b) setelah perbaikan kontras

\section{Transformasi Tophat}

Transformasi Tophat pada citra keabuan digunakan untuk merekonstruksi objek kecil dan detail yang memiliki pencahayaan background yang tidak rata dengan meningkatkan kontras. Transformasi Tophat (tophat by opening) akan menghitung perbedaan antara citra input $(f)$ dengan citra hasil opening citra input tersebut $(f \circ b)$ oleh struktur elemen $(b)$, dinyatakan dengan persamaan [17], [18]:

$$
T_{\text {hat }}(f)=f-(f \circ b)
$$

Opening dari citra $(f)$ dinyatakan dengan persamaan:

$$
f \circ b=(f \ominus b) \oplus b)
$$

Simbol $\ominus$ menyatakan proses erosi dan simbol $\oplus$ menyatakan proses dilasi di mana proses erosi dinyatakan dengan persamaan:

$$
[f \ominus b](x, y)=\min _{(s, t) \in b}\{f(x+s, y+t)-b(s, t)\}
$$

Proses dilasi dinyatakan dengan persamaan:

$$
[f \oplus b](x, y)=\max _{(s, t) \in b}\{f(x-s, y-t)+b(s, t)\}
$$

Proses erosi citra $f$ oleh struktur elemen $b$ pada titik $(x, y)$ didefinisikan sebagai nilai minimum keabuan citra pada tempat yang bertepatan dengan $b$ saat titik origin $b$ pada posisi $(x, y)$. Jadi, untuk memperoleh erosi $f$ oleh $b$, maka titik origin struktur elemen $b$ ditempatkan pada setiap lokasi piksel citra $f$, dan erosi diperoleh dari nilai minimum $f$ dari semua nilai $f$ di mana $f$ bertepatan dengan $b$. Sedangkan proses dilasi citra $f$ oleh struktur elemen $b$ pada titik $(x, y)$ didefinisikan sebagai nilai maksimum citra saat titik origin $\hat{b}$ pada posisi $(x, y)$, dengan $\hat{b}$ merupakan nilai struktur elemen yang diputar $180^{\circ}$ atau pencerminan nilai struktur elemen $b$ terhadap origin.

Transformasi Tophat akan melakukan operasi morfologi opening (erosi kemudian dilasi) pada citra keabuan hasil dari perbaikan kontras, kemudian citra keabuan tersebut akan dikurangi dengan citra hasil operasi morfologi opening. Berdasarkan hasil eksperimen yang telah dilakukan pada keseluruhan tahap segmentasi, maka nilai struktur elemen disk pada operasi opening dipilih dengan ukuran S1 sebesar 11. Nilai S1 dipilih dengan mempertimbangkan lebar piksel pembuluh darah terbesar sehingga dapat memberikan hasil terbaik untuk memisahkan pembuluh darah dan background. Citra hasil transformasi Tophat ditunjukkan pada Gambar 4.

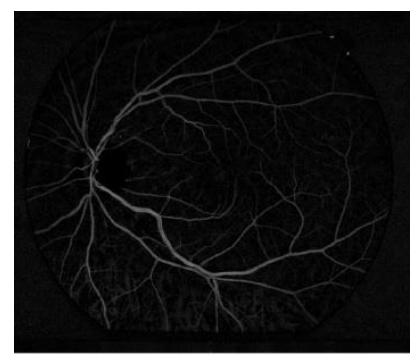

Gambar 4. Citra hasil transformasi Tophat

\section{Filter Wiener}

Filter Wiener dioperasikan pada citra keabuan dengan menggunakan pendekatan statistik berdasarkan piksel yang berdampingan. Filter Wiener digunakan untuk mengurangi noise dan efek blur pada citra retina [19]. Citra hasil filter Wiener ditunjukkan pada Gambar 5.

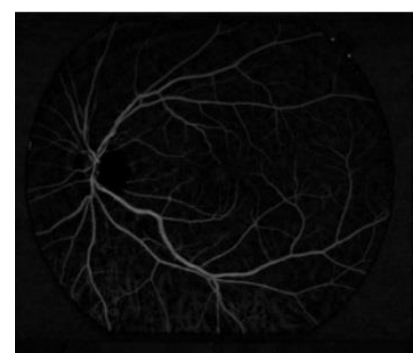

Gambar 5. Citra retina hasil filter Wiener

\section{E. Binerisasi}

Citra retina hasil filter Wiener diubah ke dalam citra biner yang hanya mempunyai dua nilai warna, yaitu hitam dan putih. Tahap ini diperlukan untuk memisahkan objek, dalam hal ini pembuluh darah, dari background. Dalam penelitian ini binerisasi citra dilakukan dengan menggunakan metode Otsu. Secara umum, untuk menghasilkan citra biner $g(x, y)$ dari suatu citra $f(x, y)$ dapat dinyatakan sebagai [20]:

$$
g(x, y)=\left\{\begin{array}{l}
1, j i k a f(x, y)>t \\
0, \text { jika } f(x, y) \leq t
\end{array}\right.
$$

di mana $t$ adalah nilai ambang (threshold). Pada metode Otsu, nilai ambang diperoleh berdasarkan sebaran nilai intensitas tiap piksel pada citra (histogram). Dengan mengetahui histogram citra, dapat ditentukan nilai ambang sehingga dapat dikelompokkan antara objek, dalam hal ini pembuluh darah, dan background. Nilai ambang pada metode Otsu diperoleh saat variansi intensitas antar kelompok mencapai nilai maksimal. Pada metode Otsu, probabilitas nilai intensitas $i$, $p(i)$ dalam histogram dihitung dengan persamaan:

$$
p(i)=\frac{n_{i}}{N}, \quad p(i) \geq 0, \sum_{1}^{L} p(i)=1
$$


di mana $n_{i}$ menyatakan jumlah piksel berintensitas i, N menyatakan jumlah semua piksel dalam citra, dan $\mathrm{L}$ menyatakan jumlah level keabuan (256 level). Kemudian histogram dibagi menjadi dua kelompok (background dan pembuluh darah) dan bobot dari masing-masing kelompok dinyatakan sebagai:

$$
\begin{gathered}
w_{1}(t)=\sum_{i=0}^{t} p(i) \\
w_{2}(t)=\sum_{i=t+1}^{L-1} p(i)=1-w_{1}(t)
\end{gathered}
$$

dengan level piksel dari background yaitu $[0,1, \ldots, t]$ dan level piksel dari pembuluh darah adalah $[t+1, \ldots ., L-1]$. Rata-rata kedua kelompok dihitung dengan persamaan:

$$
\begin{gathered}
m_{1}(t)=\sum_{i=0}^{t} \frac{i \cdot p(i)}{w_{1}(t)} \\
m_{2}(t)=\sum_{i=t+1}^{L-1} \frac{i \cdot p(i)}{w_{2}(t)}
\end{gathered}
$$

Varians antar kelompok dapat dinyatakan dengan persamaan:

$$
\sigma_{B}^{2}(t)=w_{1}(t) \cdot w_{2}(t) \cdot\left[m_{2}(t)-m_{1}(t)\right]^{2}
$$

Persamaan (7) sampai dengan persamaan (11) diulangi sebanyak $L$ dan nilai ambang $t$ diperoleh saat nilai varians antar kelompok mencapai maksimum

Pada MATLAB, penentuan nilai threshold dengan metode Otsu menggunakan fungsi graythresh, sedangkan proses segmentasinya menggunakan fungsi im $2 b w$. Citra retina biner dengan metode Otsu ditunjukkan pada Gambar 6.

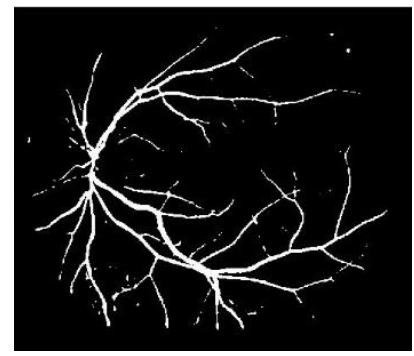

Gambar 6. Citra hasil binerisasi

\section{F. Masking}

Proses masking digunakan untuk mendapatkan ROI [6]. Masking dari citra fundus pada dasarnya adalah sebuah citra biner yang terdiri dari 0 (hitam) dan 1 (putih). Daerah retina berbentuk lingkaran direpresentasikan dengan 1 pada citra retina persegi, sehingga proses masking harus dilakukan untuk memilih ROI [21]. Dalam penelitian ini, masking dibuat berdasarkan nilai ambang yang dipilih bagi komponen hue dan saturasi dalam ruang warna HSV untuk memilih daerah retina. Operasi logika AND antara citra masking dengan citra biner dari proses binerisasi dengan metode Otsu akan menghasilkan citra biner di dalam ROI. Citra biner retina di dalam ROI masih mengandung noise. Apabila noise tersebut tidak dihilangkan, noise akan dianggap sebagai bagian pembuluh darah sehingga perlu dilakukan penghapusan area objek kecil yang memiliki piksel kurang dari S3 dengan nilai S3 yang diatur sebesar 500 seperti ditunjukkan pada Gambar 7.

\section{G. Proses Iterasi}

Proses iterasi dilakukan untuk memperbaiki hasil segmentasi citra. Citra biner di dalam ROI digunakan sebagai frame acuan dan dinyatakan sebagai citra biner referensi. Iterasi menurun dilakukan mulai dari transformasi Tophat sampai dengan Otsu thresholding, serta operasi logika AND antara citra biner dan citra masking. Indeks iterasi pada proses ini merupakan ukuran struktur elemen mulai dari S1-1 hingga S2 dan nilai struktur elemen $\mathrm{S} 2$ diatur ke 5 dengan mempertimbangkan lebar pembuluh darah. Seiring dengan menurunnya iterasi, area noise biasanya lebih lebar. Ukuran S3 pada pembuangan objek kecil ditingkatkan sebesar 10 untuk setiap proses iterasi agar diperoleh hasil segmentasi yang optimal agar hal masalah tersebut dapat teratasi. Langkah terakhir dari proses iterasi adalah menerapkan operasi logika OR antara citra biner referensi dengan citra yang diperoleh dari setiap iterasi. Proses iterasi tersebut membuat hasil segmentasi citra yang diperoleh menjadi lebih optimal. Langkah dalam proses iterasi ditunjukkan pada Gambar 8 .

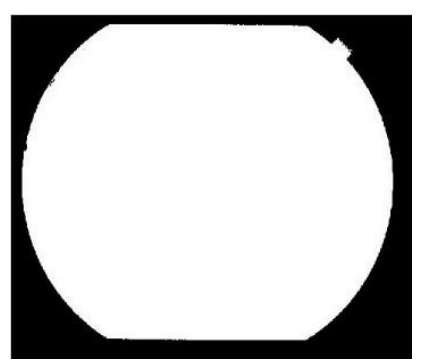

(a)

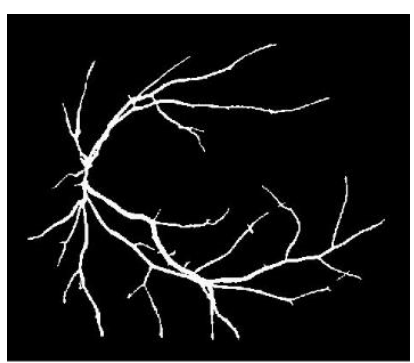

(b)
Gambar 7. Citra biner retina (a) masking citra dan (b) citra biner setelah operasi logika AND dan pembuangan noise

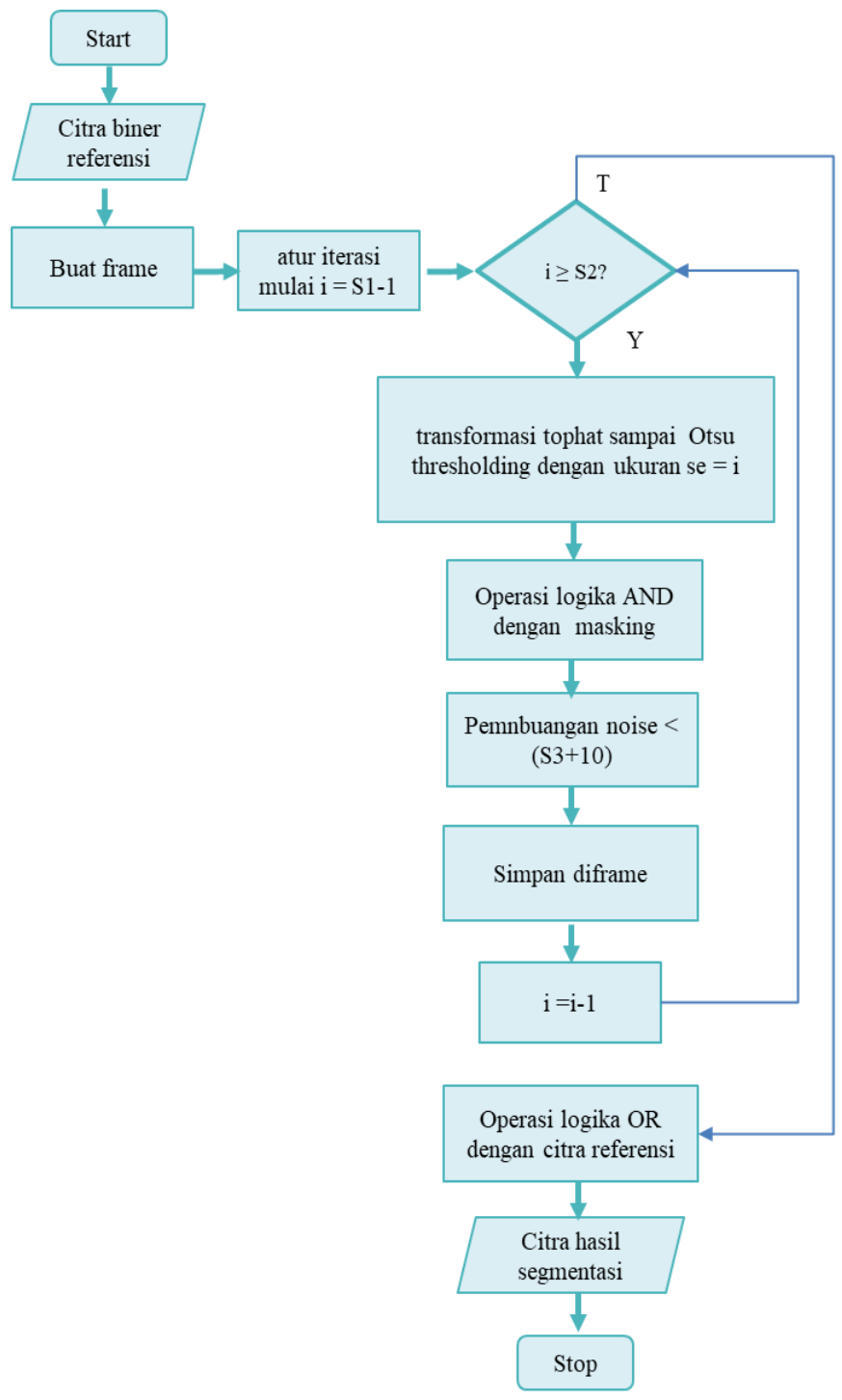

Gambar 8. Langkah proses iterasi 
Citra biner hasil proses segmentasi yang diperoleh dari operasi logika OR antara citra referensi dengan citra dari proses iterasi ditunjukkan pada Gambar 9.

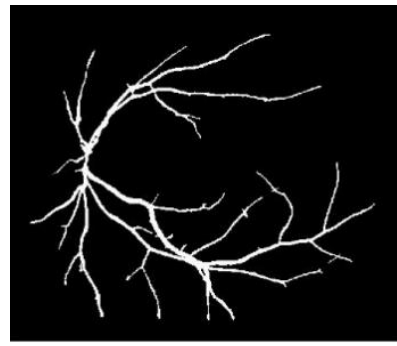

(a)

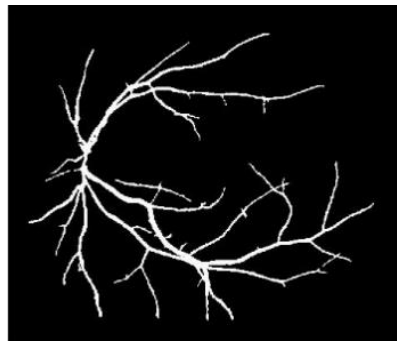

(b)
Gambar 9. Citra biner retina hasil proses segmentasi (a) sebelum proses iterasi dan (b) setelah proses iterasi

\section{HASIL DAN PEMBAHASAN}

Kinerja metode segmentasi dalam penelitian ini dilakukan dengan membandingkan citra hasil segmentasi dengan citra ground truth, yaitu citra segmentasi manual yang terdapat pada dataset STARE yang tersedia secara publik. Seperti yang telah dijelaskan dalam Bagian II, dataset STARE terdiri dari 20 citra fundus beserta hasil segmentasi manual dari dua orang pengamat. Terdapat empat kondisi saat citra hasil segmentasi dibandingkan dengan ground truth, yaitu True Positive (TP) yang merupakan jumlah piksel bernilai 1 pada citra yang sesuai dengan dataset bernilai 1, True Negative (TN) adalah jumlah piksel bernilai 0 pada citra yang sesuai dengan dataset bernilai 0 , False Positive $(F P)$ adalah jumlah piksel bernilai 1 pada citra yang sesuai dengan dataset yang bernilai 0, dan False Negative $(F N)$ adalah jumlah piksel bernilai 0 pada citra yang sesuai dengan dataset bernilai 1 [22], [23]. Perbandingan definisi TP, $T N, F P$, dan $F N$ berdasarkan ada tidaknya pembuluh darah dengan terdeteksinya pembuluh darah ditunjukkan pada Tabel I [1].

TABEL I. DEFINISI TP, TN, FP, DAN FN

\begin{tabular}{ccc}
\hline \hline Keterangan & $\begin{array}{c}\text { Pembuluh darah } \\
\text { ada }\end{array}$ & $\begin{array}{c}\text { Pembuluh darah } \\
\text { tidak ada }\end{array}$ \\
\hline $\begin{array}{c}\text { Pembuluh darah } \\
\text { terdeteksi }\end{array}$ & $\mathrm{TP}$ & $\mathrm{FP}$ \\
$\begin{array}{c}\text { Pembuluh darah } \\
\text { tidak terdeteksi }\end{array}$ & $\mathrm{FN}$ & $\mathrm{TN}$ \\
\hline \hline
\end{tabular}

Berdasarkan kondisi pada Tabel I tersebut, dilakukan evaluasi terhadap lima indikator untuk menilai kinerja metode segmentasi yang diusulkan dalam penelitian ini, yaitu akurasi $(A c c)$, spesifisitas $(S p)$, sensitivitas $(S e)$, presisi atau positive prediction value $(P p v)$, dan dice coefficient $(D c)$. Acc adalah perbandingan jumlah piksel yang diklasifikasikan dengan benar terhadap jumlah total piksel di dalam citra. Akurasi menunjukkan kinerja segmentasi secara keseluruhan [18]. Sp adalah perbandingan jumlah piksel bukan pembuluh darah yang diklasifikasikan dengan benar terhadap jumlah total piksel bukan pembuluh darah di dalam citra dataset. Spesifisitas mengukur kemampuan algoritma untuk mendeteksi piksel yang bukan pembuluh darah [4]. Se adalah perbandingan jumlah piksel pembuluh darah yang terdeteksi dengan benar terhadap jumlah piksel pembuluh darah di dalam citra dataset. Sensitifitas mengukur kemampuan algoritma untuk mendeteksi piksel pembuluh darah [24]. $P p v$ merupakan perbandingan jumlah piksel pembuluh darah yang terdeteksi dengan benar terhadap keseluruhan pembuluh darah yang terdeteksi. Selain indikator tersebut, terdapat indikator $D c$ yang digunakan untuk menghitung kemiripan antara dua buah citra secara statistik. Nilai $D c$ diperoleh dengan membandingkan jumlah piksel citra yang sama dengan keseluruhan piksel yang ada. Semua indikator evaluasi tersebut dinyatakan dengan persamaan [25], [26]:

$$
\begin{gathered}
\text { Akurasi }\left(A_{c c}\right)=\frac{T P+T N}{T P+F N+T N+F P} \\
\text { Spesifisitas }\left(S_{p}\right)=\frac{T N}{T N+F P} \\
\text { Sensitifitas }\left(S_{e}\right)=\frac{T P}{T P+F N} \\
\text { Presisi }\left(P_{p v}\right)=\frac{T P}{T P+F P} \\
\text { Dice Coefficient }(D c)=\frac{2 T P}{2 T P+F P+F N}
\end{gathered}
$$

Nilai indikator evaluasi citra hasil segmentasi terhadap ground truth ditunjukkan pada Tabel II. Hasil evaluasi kinerja metode segmentasi ini terhadap 20 citra dataset STARE dari pengamat 1 ditunjukkan pada Gambar 10. Sedangkan hasil evaluasi kinerja metode segmentasi ini terhadap 20 citra dataset STARE dari pengamat 2 ditunjukkan pada Gambar 11.

TABEL II. HASIL KINERJA SEgMENTASI TERHADAP GROUND TRUTH

\begin{tabular}{cccccc}
\hline \hline $\begin{array}{c}\text { Pengamat } \\
\text { (ground truth) }\end{array}$ & $\begin{array}{c}\text { Acc } \\
(\boldsymbol{\%})\end{array}$ & $\begin{array}{c}\text { Sp } \\
(\boldsymbol{\%})\end{array}$ & $\begin{array}{c}\text { Se } \\
(\boldsymbol{\%})\end{array}$ & $\begin{array}{c}\text { Ppv } \\
(\boldsymbol{\%})\end{array}$ & $\begin{array}{c}\text { Dc } \\
(\boldsymbol{\%})\end{array}$ \\
\hline 1 & 94,88 & 97,94 & 62,65 & 79,76 & 68,47 \\
2 & 92,31 & 98,31 & 50,18 & 81,20 & 59,64 \\
Rata-rata & 93,60 & 98,13 & 56,42 & 80,48 & 64,06 \\
\hline \hline
\end{tabular}

Hasil Evaluasi Kinerja Segmentasi (Pengamat 1)

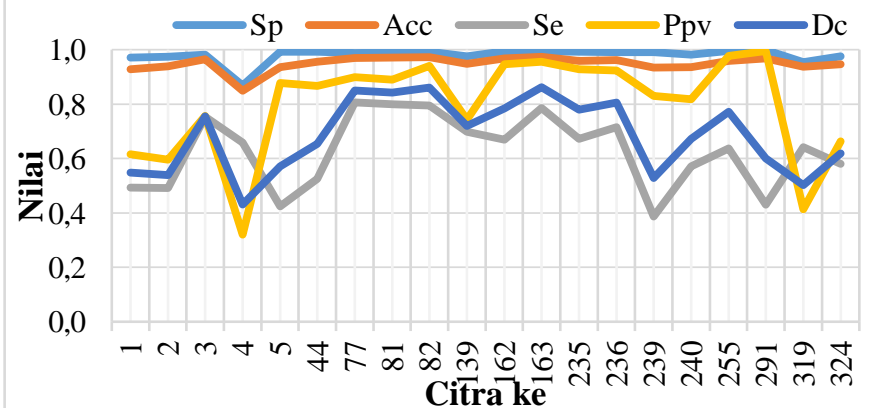

Gambar 10. Nilai Sp, Acc, Sp, Ppv, dan Dc untuk 20 citra hasil segmentasi terhadap pengamat

Hasil Evaluasi Kinerja Segmentasi (Pengamat 2)

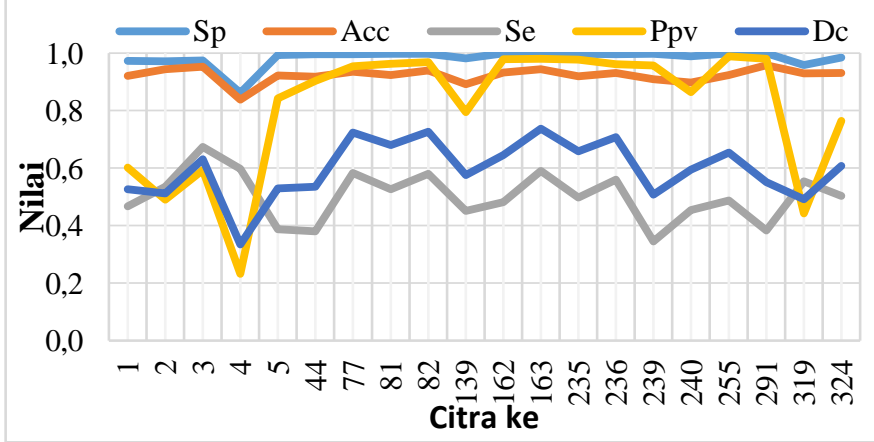

Gambar 11. Nilai Sp, Acc, Sp, Ppv, dan Dc untuk 20 citra hasil segmentasi terhadap pengamat 2

Berdasarkan Tabel II, algoritma yang diusulkan dalam penelitian ini mampu secara otomatis mensegmentasi pembuluh darah retina dengan akurasi $(A c c)$ sebesar 93,60\%, spesifisitas (Sp) sebesar 98,13\%, sensitifitas (Se) sebesar $56,42 \%$, presisi (Ppv) sebesar 80,48\%, dan Dice coefficient (Dc) sebesar $64,06 \%$. Berdasarkan nilai $S p$ yang ditunjukkan pada 
Tabel II, dapat diketahui bahwa algoritma tersebut sangat baik dalam mengidentifikasi piksel bukan pembuluh darah dengan tingkat positif palsu $(F P)$ yang rendah. Hal ini menandakan bahwa hanya sedikit piksel bukan pembuluh darah yang terdeteksi sebagai pembuluh darah. Sedangkan nilai Se yang cukup rendah menandakan bahwa banyak piksel pembuluh darah yang tidak terdeteksi terutama terhadap pengamat 2 . Hal ini terjadi karena pengamat 2 mensegmentasi pembuluh darah yang sangat kecil dan tipis. Pembuluh darah tersebut tidak mampu diekstraksi oleh algoritma segmentasi yang diusulkan, seperti ditunjukkan pada gambar citra pengamat 2 pada Tabel III. Karena hal itu pula, beberapa penelitian ([1], [7] dan [10]) hanya menggunakan pengamat 1 sebagai ground truth. Penggunaan transformasi Tophat dengan pemilihan iterasi yang tepat mulai S1 sampai S2 secara umum akan mampu merekonstruksi pembuluh darah di dalam citra retina. Penelitian sebelumnya yang berbasis operasi morfologi [7] hanya menggunakan satu nilai struktur elemen. Proses iterasi menurun dalam penelitian ini akan memperbaiki hasil segmentasi sehingga mampu merekonstruksi pembuluh darah besar dan kecil, walaupun pembuluh yang sangat kecil masih belum tercakup. Dalam beberapa kali pengujian, diperoleh bahwa peningkatan spesifisitas akan menyebabkan penurunan sensitivitas. Hal tersebut menjadi tantangan dalam penelitian ini.

Berdasarkan grafik pada Gambar 10 dan Gambar 11, diketahui bahwa beberapa citra mempunyai nilai evaluasi kinerja yang rendah. Hal ini disebabkan karena citra hasil segmentasi tersebut masih mengandung noise akibat adanya kondisi patologis, kontras yang rendah antara pembuluh darah dan background, ataupun citra yang blur. Namun demikian, nilai Acc yang cukup baik menandakan bahwa algoritma segmentasi yang diusulkan mampu untuk mengklasifikasikan piksel pembuluh darah dan piksel bukan pembuluh darah dengan benar. Nilai indikator $D c$ yang diperoleh menunjukkan bahwa hasil segmentasi pembuluh darah citra retina yang diusulkan mempunyai kemiripan dengan ground truth sebesar $64,06 \%$.

Tabel III menunjukkan tiga buah citra retina RGB di dalam dataset STARE beserta citra hasil segmentasi yang dibandingkan dengan citra ground truth dari pengamat 1 dan pengamat 2. Grafik perbandingan kinerja dari metode ini dengan beberapa penelitian terkait yang menggunakan dataset STARE ditunjukkan pada Gambar 12.

Grafik pada Gambar 12 menunjukkan perbandingan nilai $A c c, S p$, dan $S e$ terhadap pengamat 1 sebagai ground truth karena penelitian-penelitian sebelumnya umumnya hanya mengukur ketiga kinerja segmentasi tersebut. Berdasarkan grafik tersebut, penelitian ini mempunyai nilai akurasi dan spesifisitas yang lebih baik jika dibandingkan dengan penelitian [9] dan [5], walaupun masih tidak sebaik penelitian [1], [7], dan [10]. Nilai akurasi dan spesifisitas yang tinggi menunjukkan bahwa kinerja segmentasi otomatis ini sangat baik untuk digunakan dan dapat menggantikan segmentasi manual yang memiliki banyak kelemahan, antara lain waktu pemrosesan yang lama serta tingkat variabilitas hasil segmentasi manual yang cukup tinggi dari setiap pengamat. Selain itu, metode segmentasi dalam penelitian ini mudah untuk diimplemetasikan dan tidak bergantung pengamat, apabila dibandingkan dengan segmentasi manual. Dengan hasil segmentasi yang diperoleh, tahap pemrosesan citra retina selanjutnya dapat diimplementasikan.

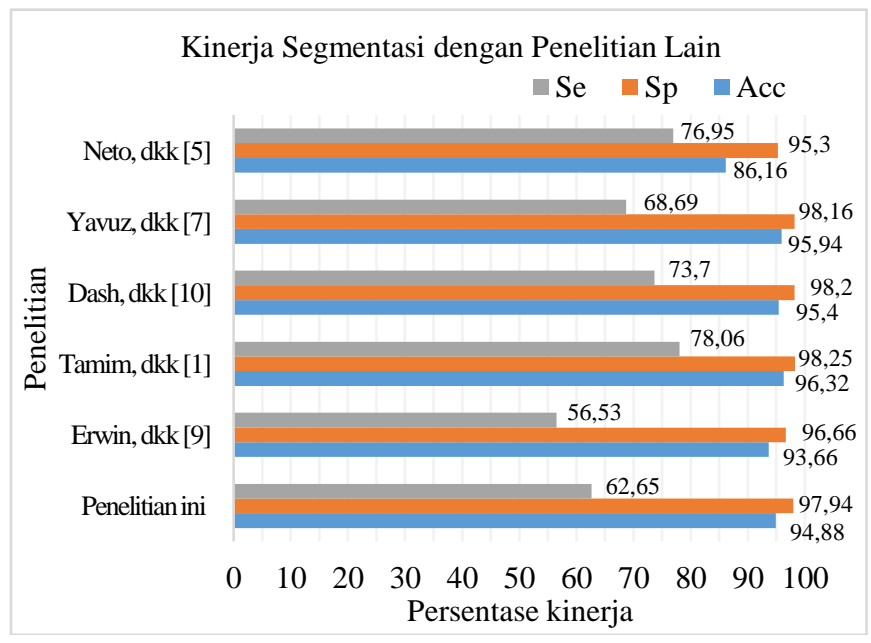

Gambar 12. Kinerja segmentasi beberapa penelitian

TABEL III. Hasil Segmentasi Dibandingkan dengan Citra Pengamat 1 dan Pengamat 2 dalam Dataset STARE

\begin{tabular}{llll}
\hline \multicolumn{1}{c}{ Citra } & Citra 077 & Citra 162 \\
RGB \\
Citra hasil \\
segmentasi
\end{tabular}




\section{IV.PENUTUP}

Metode yang diusulkan dalam penelitian ini telah terbukti berhasil melakukan segmentasi otomatis citra pembuluh darah retina. Transformasi Tophat dengan pemilihan ukuran nilai struktur elemen dan iterasi yang tepat menentukan daerah yang akan disegmentasi dengan metode Otsu. Berdasarkan hasil evaluasi kinerja yang dilakukan, metode tersebut sudah cukup baik mengekstraksi pembuluh darah pada citra retina. Namun demikian, metode segmentasi yang diajukan belum secara optimal mampu mengekstraksi pembuluh darah yang sangat kecil dan tipis, belum optimal mengatasi kontras yang rendah, serta belum optimal dalam mengekstraksi pembuluh darah di mana terdapat pengaruh noise yang besar pada ROI citra retina akibat beberapa kondisi patologis, kontras yang rendah antara pembuluh darah dan background, ataupun citra yang blur. Oleh karena itu, diperlukan beberapa perbaikan yang dapat meningkatkan hasil segmentasi, antara lain dengan teknik ekualisasi histogram adaptif pada tahap perbaikan kontras, penggunaan teknik masking yang adaptif sehingga mampu mengekstraksi ROI berbagai citra retina yang mempunyai nilai hue dan saturasi beragam, memodifikasi transformasi Tophat, atau dengan menggunakan beberapa tahap operasi morfologi lain dengan jenis dan nilai struktur elemen yang tepat sehingga mampu merekonstruksi segmen pembuluh darah tipis serta mampu mengatasi noise.

\section{REFERENSI}

[1] N. Tamim, M. Elshrkawey, G. A. Azim, and H. Nassar, "Retinal blood vessel segmentation using hybrid features and multi-layer perceptron neural networks," Symmetry (Basel)., vol. 12, no. 6, 2020, doi: 10.3390/SYM12060894.

[2] M. K. Fadafen, N. Mehrshad, and S. M. Razavi, "Detection of diabetic retinopathy using computational model of human visual system,' Biomed. Res., vol. 29, no. 9, pp. 1956-1960, 2018, doi 10.4066/biomedicalresearch.29-18-551.

[3] Y. Guo and Y. Peng, "BSCN: Bidirectional symmetric cascade network for retinal vessel segmentation," BMC Med. Imaging, vol. 20, no. 1, pp. 1-22, 2020, doi: 10.1186/s12880-020-0412-7.

[4] Aastha and R. Gautam, "A review on retinal blood vessel segmentation methodologies," Int. J. Sci. Technol. Res., vol. 8, no. 9, pp. 738-747, 2019.

[5] L. Câmara Neto, G. L. B. Ramalho, J. F. S. Rocha Neto, R. M. S. Veras, and F. N. S. Medeiros, "An unsupervised coarse-to-fine algorithm for blood vessel segmentation in fundus images," Expert Syst. Appl., vol. 78, pp. 182-192, 2017, doi: 10.1016/j.eswa.2017.02.015.

[6] J. Almotiri, K. Elleithy, and A. Elleithy, "Retinal vessels segmentation techniques and algorithms: A survey," Appl. Sci., vol. 8, no. 2, 2018, doi: 10.3390/app8020155.

[7] Z. Yavuz and C. Köse, "Blood Vessel Extraction in Color Retinal Fundus Images with Enhancement Filtering and Unsupervised Classification," J. Healthc. Eng., vol. 2017, 2017, doi: $10.1155 / 2017 / 4897258$.

[8] A. Ali, A. Hussain, and W. M. D. Wan Zaki, "Segmenting retinal blood vessels with gabor filter and automatic binarization," Int. J. Eng. Technol., vol. 7, no. 4, pp. 163-167, 2018, doi: 10.14419/ijet.v7i4.11.20794.

[9] Erwin, a. Rohman, L. a. Nurjanah, Yurika, D. Sinta, and Q. Al'Afwa, "New techniques for segmentation and extraction retinal blood vessels," J. Phys. Conf. Ser., vol. 1500, no. 1, 2020, doi: 10.1088/1742 6596/1500/1/012090.
[10] J. Dash and N. Bhoi, "Retinal blood vessel segmentation using Otsu thresholding with principal component analysis," in Proc. 2nd Int. Conf. Inven. Syst. Control, ICISC 2018, pp. 933-937, 2018, doi: 10.1109/ICISC.2018.8398938.

[11] U. Ozkava, S. Ozturk, B. Akdemir, and L. Sevfi, “An Efficient Retinal Blood Vessel Segmentation using Morphological Operations," in ISMSIT 2018 - 2nd Int. Symp. Multidiscip. Stud. Innov. Technol. Proc., pp. 1-7, 2018, doi: 10.1109/ISMSIT.2018.8567239.

[12] Z. Jiang, H. Zhang, Y. Wang, and S. B. Ko, "Retinal blood vessel segmentation using fully convolutional network with transfer learning," Comput. Med. Imaging Graph., vol. 68, no. April, pp. 1-15, 2018, doi 10.1016/j.compmedimag.2018.04.005.

[13] N. Memari, A. R. Ramli, M. I. Bin Saripan, S. Mashohor, and M Moghbel, "Retinal Blood Vessel Segmentation by Using Matched Filtering and Fuzzy C-means Clustering with Integrated Level Set Method for Diabetic Retinopathy Assessment," J. Med. Biol. Eng., vol. 39, no. 5, pp. 713-731, 2019, doi: 10.1007/s40846-018-0454-2.

[14] A. Hoover, "Locating blood vessels in retinal images by piecewise threshold probing of a matched filter response," IEEE Trans. Med. Imaging, vol. 19, no. 3, pp. 203-210, 2000, doi: 10.1109/42.845178.

[15] M. Alam, T. Son, D. Toslak, J. I. Lim, and X. Yao, "Combining ODR and blood vessel tracking for artery-vein classification and analysis in color fundus images," Transl. Vis. Sci. Technol., vol. 7, no. 2, 2018, doi: 10.1167/tvst.7.2.23

[16] D. A. Palanivel, S. Natarajan, and S. Gopalakrishnan, "Retinal vessel segmentation using multifractal characterization," Appl. Soft Comput. J. vol. 94, p. 106439, 2020, doi: 10.1016/j.asoc.2020.106439.

[17] D. Sutaji, C. Fatichah, and D. A. Navastara, "Segmentasi Pembuluh Darah Retina pada Citra Fundus Menggunakan Gradient Based Adaptive Thresholding dan Region Growing," Regist. J. Ilm. Teknol. Sist. Inf., vol. 2, no. 2, p. 105, 2016, doi: 10.26594/register.v2i2.553.

[18] S. Aswini, a. Suresh, S. Priya, and B. V. Santhosh Krishna, "Retinal vessel segmentation using morphological top hat approach on diabetic retinopathy images," in Proc. 4th IEEE Int. Conf. Adv. Electr. Electron. Information, Commun. Bio-Informatics, AEEICB 2018, pp. 1-5, 2018, doi: 10.1109/AEEICB.2018.8480970.

[19] R. P. Sari, "Enhancement Citra Fundus Retina Menggunakan CLAHE dan Wiener Filter," Ars, vol. 4, no. 1, pp. 978-979, 2018.

[20] M. Santoso, T. Indriyani, and R. E. Putra, "Deteksi Microaneurysms pada Citra Retina Mata Menggunakan Matched Filter," INTEGER J. Inf. Technol., vol. 2, no. 2, pp. 59-68, 2017, [Online]. Available: https://ejurnal.itats.ac.id/integer/article/view/180/97.

[21] M. Garg and S. Gupta, "Generation of binary mask of retinal fundus image using bimodal masking," J. Adv. Res. Dyn. Control Syst., vol. 10, no. 6 , pp. $1777-1786,2018$

[22] K. Yota, E. Aryanto, and I. K. E. Purnama, "Segmentasi Pembuluh Darah Pada Citra Retina Menggunakan Max-Tree dan Attribute Filtering," in SNATI, vol. 2009, 2009.

[23] F. Sabaz and U. Atila, "ROI detection and vessel segmentation in retinal image," Int. Arch. Photogramm. Remote Sens. Spat. Inf. Sci. - ISPRS Arch., vol. 42, no. 4W6, pp. 85-89, 2017, doi: 10.5194/isprs-archivesXLII-4-W6-85-2017.

[24] L. Farosanti and C. Fatichah, "Perbaikan Segmentasi Pembuluh Darah Tipis Pada Citra Retina Menggunakan Fuzzy Entropy,” JUTI J. Ilm. Teknol. Inf., vol. 17, no. 2, p. 135, 2019, doi: 10.12962/j24068535.v17i2.a857.

[25] Y. Yu and H. Zhu, "Retinal vessel segmentation with constrained-based nonnegative matrix factorization and 3D modified attention U-Net," Eurasip J. Image Video Process., vol. 2021, no. 1, 2021, doi: 10.1186/s13640-021-00546-6.

[26] C. Bhardwaj, S. Jain, and M. Sood, "Automatic blood vessel extraction of fundus images employing fuzzy approach," Indones. J. Electr. Eng. Informatics, vol. 7 , no. 4, pp. 757-771, 2019, doi: 10.11591/ijeei.v7i4.991. 